\title{
DEVELOPING INTERACTIVE LISTENING LEARNING MULTIMEDIA TO SUPPORT "BAHASA INGGRIS FOR GRADE TEN" BOOK
}

\author{
Izzul Amal, Ikhsanudin, Eusabinus Bunau \\ English Education Study Program of Teacher Training and Education Faculty \\ Tanjungpura University, Pontianak \\ Email:izzulamal@student.untan.ac.id
}

\begin{abstract}
This research was conducted to design Interactive Listening Learning Multimedia; an interactive multimedia as a teaching and learning media to support "Bahasa Inggris for Grade Ten" book. The research aims to determine whether the interactive listening learning multimedia as the supplementary teaching media is usable to support "Bahasa Inggris for Grade Ten" book or not. The form of this research is developmental research. The method of this research was design and development research. The researcher applied ADDIE as the procedure. In this research, the researcher only implemented three phases which are analysing, designing, and developing (ADD) because of time limitation. The interview for analysing phase was administered in SMA Muhammadiyah 1 Pontianak. The researcher created the multimedia using Powerpoint. In development phase, the researcher used internal evaluation to make sure that the multimedia is usable. To sum up, it is found that interactive listening learning multimedia is usable to support "Bahasa Inggris for Grade Ten" Book.
\end{abstract}

Keywords: Development Research, Interactive Multimedia, Listening

To cite this paper (in APA style):

Amal, I., Ikhsanudin, \& Bunau, E. (2021). Developing interactive listening learning multimedia to support "Bahasa Inggris for Grade Ten" book. Journal of English Education Program, 2(1), 30-38. http:/ / dx.doi.org/10.26418/jeep.v2i1.42289

\section{INTRODUCTION}

The English teaching in senior high school level in Indonesia has reformed to Curriculum of 2013 (K13). The purpose of English teaching is to make the students able to use all language skills which are speaking, writing, listening, and reading. In order to enhance students' skills and achieve the goal of English teaching, these skills ought to be taught in balance.

There are four skills of English language that should be taught in balance, Nation and Newton (2009) believes that in order to refine students' language competence, EFL students who study English use most of their time to have listening activities. English listening competence is important to give input in order to enhance the proficiency of students' language. The input has an important role for the students in order to produce spoken language. The 
students will acquire the language easier if listening exercises are arranged before other activities. Hence, in order to enhance the students' language skill, listening activities should be a priority.

A large number of listening audios at senior high school were mp3 and Youtube videos. These listening audios are played by the Teachers using sound speaker. The students were less interested to the audio because the chance of listening the audio is only once. The students would rather have a multimedia that provides audio materials.

Most of the schools have language or computer laboratories currently. However, there are some senior high schools that have not used the laboratories optimally, for instance SMA Muhammadiyah 1 Pontianak. Finding appropriate multimedia that suits the student needs is difficult for the teacher. Therefore, the teacher ought to develop their own multimedia. The problem is the teacher do not have sufficient time for developing the multimedia. Hence, the material from textbook are often used in English learning and teaching process.

The application of the latest curriculum is related to improve students' listening skills. Teachers should give appropriate listening audio in order to improve students' listening skill. The English teachers in this school use an English textbook entitled "Bahasa Inggris for Grade Ten" as main source of the materials. The materials in this book are in line with the latest curriculum. The book provides material in form of text and images. Teacher act as a model for listening materials.

Without using any multimedia and only using material from textbook, the teaching and learning will become ineffective. There are three reasons for that. First, this textbook does not contain listening audio. Therefore, the listening input only come from the teacher. Second, the listening practices from the textbook is monotonous that can make the students get bored. Third, the audio recording is more attractive than the spoken output from the teacher. Therefore, the students are less attracted to learn the materials.

In relation to the use of listening materials, studies by Ikhsanudin, Sudarsono \& Salam (2019) and Purwanto, Ikhsanudin \& Susilawati (2017) shows that supplementary listening materials and unique learning style can stimulate the students' engagement to learn English. Purwanto, Ikhsanudin \& Susilawati (2017) applied "magic-tricks" problem-based activities in teaching listening whereas Purwanto, Ikhsanudin \& Susilawati (2017) produced suitable listening workbook. These studies were accomplished to fulfil the gap on the syllabus of latest curriculum regarding to listening materials. Therefore, the studies showed that supplementary listening materials and unique teaching style can enhance students' engagement in learning listening. In this research, the researcher tried to expand the materials from those previous studies into something interactive. The students were not only able to listen to the materials, but the students were also able to interact by answering some questions related to the audio material. Based on the problems above, the researcher decided to solve the problem in order to help the students in learning listening. The solution is to develop appropriate interactive listening learning multimedia that the material is based 
on the "Bahasa Inggris for Grade Ten" book. The multimedia is based on that book so the development of the multimedia is based on Curriculum 2013. Hence, interactive listening learning multimedia has been developed.

According to Mishra and Sharma (2005), conventional media is often used with combining traditional teaching approach like lectures to achieve teaching purposes, for instance adapting to individual learning styles, clarifying complex subjects, aiding recall, retention improvement, and reaching nonverbal learners. According to Oxford English Dictionary (n.d.), Interactive means proceeding an interpersonal flow of direction between a system and a user. Mishra and Sharma (2005) claimed that the interactive multimedia is a software that provides information and it can be recognized by pictures, text, animation, sound and video. From the explanations above, it can be concluded that interactive learning multimedia is a software that can provide video, audio, text, animation, and graphic that allows the students to control the learning flow in the multimedia. In this research, the researcher used ADDIE by Branch (2009) as the method to create the product. ADDIE stands for analysing, design, develop, implement and evaluate. The research was ended in development phase. Therefore, implementation and evaluation phase were omitted. The product of this development research consists of main menu, materials, activities, and user's guide. The interactive listening learning multimedia can be downloaded at "http:/ / bit.ly/listeningmultimedia".

\section{METHOD}

Based on the research problem, the researcher used developmental study. The objective of the development study is to produce a brand new or improved approach in order to fulfil learning goals. The researcher applied ADDIE method to develop an interactive listening learning multimedia. Referring to Branch (2009), ADDIE consists of five which are Analyze, Design, Develop, Implement, and Evaluate. This concept was suitable to use as a procedure of producing learning products. Therefore, because of the time limitation, the researcher decided to apply on three phases; Analyze, Design, and Develop (ADD).

The main purpose of the analyzing phase is to find out the possible causes of gap in learning performance (Branch, 2009). The researcher conducted an observation to the students and had an interview with the teacher. In this process, unstructured interview was conducted by the researcher which the teacher was being asked of sequenced questions that have been prepared (Cohen et al., 2007). This interview was used in order to get information about listening teaching in classroom. The details of condition of the process of listening learning and the facilities were acquired in this interview. In the analyzing phase, the researcher analyzes "Bahasa Inggris for Grade Ten" book. Then, the researcher designed criteria that include the requirements of an appropriate multimedia in order to do an internal evaluation in development phase.

In design phase, the design was based on the textbook and from the interview results as the principle in order to produce the multimedia. The researcher also considered core competences for the materials in the multimedia. Some 
materials from the book was added to complete the activities. The researcher also designed criteria that include the requirements of an appropriate multimedia in order to do an internal evaluation in development phase. The researcher also asked the teacher about what aspect that should be included in the criteria.

In developing phase, the first three units in "Bahasa Inggris for Grade Ten" become the main materials for the multimedia. The researcher performed three steps in this phase. The researcher gathered learning materials such as pictures, text, and audio in the first step. The internet and textbook have been adapted for the materials. The next step was arranging the components into interactive learning multimedia using Powerpoint. After that, the researcher created the listening audio by using a website "Animaker". The last step of this phase was internal evaluation. The internal evaluation was the most decisive step of the phase. The researcher checked and observed the multimedia to make sure that the multimedia fulfils all of the aspects in the criteria. If the multimedia meets all the requirement from the criteria, then the multimedia is considered as usable.

According to Harvey (2004), internal evaluation is a procedure to measure a quality of a product that held by an institution. While developing the multimedia, the researcher will check whether the multimedia meets the criteria that has been formulated in analyzing phase or not.

\section{RESULTS AND DISCUSSION \\ Results}

In order to gather information of listening activities, some data had been gathered by the researcher through an interview with the English teacher. Therefore, the interview results are; (1) The students found the listening exercise in the book were too difficult because the students barely had listening exercise before. (2) The "Bahasa Inggris for Grade Ten" book is used as main material in that school and the book's materials are integrated with the latest curriculum. (3) The students need new learning media in order to improve the listening activity. (4) The interactive listening learning multimedia will encourage the students to have listening activities. To sum it up, the researcher found that multimedia was needed in order to support "Bahasa Inggris for Grade Ten" as main material for learning English.

The researcher designed this product to achieve the objective to support "Bahasa Inggris for Grade Ten" book. The interactive listening learning multimedia must complete the criteria in analyzing phase. Interactive listening learning multimedia can be used in the teaching learning process for supporting listening activities. However, the material in the multimedia should be presented in a structured way in teaching and learning activity (Branch, 2009).

In design phase, materials from the textbook was chosen for the multimedia. This phase was important because the teacher wants the materials in the multimedia related to the textbook. The researcher named this product as 
"Interactive Listening Learning Multimedia". The term "interactive" in the name of this multimedia means that this multimedia requires the user to give input (mouse click) in order to use the multimedia. The interactive multimedia also has navigation buttons that help the students go to another material easily so the students have their own control with their learning. In the first menu, the researcher presented a start menu by put the title of the electronic presentation. The researcher also showed the animated background to make the slide look interesting and hoped the first slide can entertain the user of interactive listening learning multimedia. Moreover, the researcher put a suggestion to wear a headphone before the first menu.

Each unit have three activities or exercises. First activity is a true/false activity. The students have to listen to the audio by clicking the play button to choose true or false based on the statement. The second activity is filling the blank. There is a missing line in a dialogue that the students should fill by listening each of the answers and choose the right answer. The last activity is an objective test. The students have to click the play button to listen the question. After that, the students choose the right answer by clicking one of each answer given. In every unit, there are dialogues in form of text and audio. The students can hear the audio of each lines in the dialogue by clicking the lines.

Furthermore, the teacher might use this multimedia for 6 meetings or more meetings depending on the teacher's decision according to the syllabus and curriculum in the school. The researcher created interactive listening learning multimedia in order to make a flexible material. Therefore, other teaching activities might be used with this multimedia.

The researcher also provided the school with this multimedia through software format and in Compact Disc form for using it as supplementary materials for the students. In addition, because of the materials in the multimedia were general, the researcher really hopes that interactive multimedia would be used by the other English teachers in the future. In design phase, a software is important for developing the final product later. Therefore, software for developing the multimedia has been chosen by considering to the features of the software itself. Microsoft PowerPoint 2019 was the first software. It can produce a presentation that contains different kind of graphic that can be useful to present the materials. Fisher (2003) found that PowerPoint is a multimedia presentation software which can present various style of text display and graphic. PowerPoint is a useful application that can produce enhanced presentation, presenting ideas in a good visual. This software meant to supplement the presentation software, the text, object, graphics, video, sound and other object positioned in multiple individual pages called "slide". Each slide can be printed or displayed on the screen and can be navigated through the command of the presenter.

The second software is a website named "Animaker". This website contains Text-To-Speech (TTS) feature that can produce voices from texts that has been inputted. Therefore, this website is called a dictation website that produce voices. This website also allows the user to alter a voice parameter (rate and 
pitch) and improve the voice's articulation quality. This website was used in order to create listening audio for dialogues and texts in multimedia.

In developing phase, the researcher began to create the multimedia using PowerPoint and Animaker. This multimedia can be downloaded in this link "http:/ / bit.ly/listeningmultimedia". The researcher chose "bit.ly" and "Google Drive" website as the source to download the multimedia because the link can be shrinked into shorter link. Therefore, it is easier to download the multimedia because the link is easy to remember. There are numbers of website or services that can be used to upload the multimedia. Slideshare, Google Drive, and Dropbox are the examples. The researcher chose Google Drive because of the upload and download speed is the fastest than the other websites. Therefore, the user can download the multimedia in a short time. The software used by the researcher in this phase are "Power Point" and "Animaker". The process of the developing phase consists of develop, self-evaluation, small-scale implementation and revision.

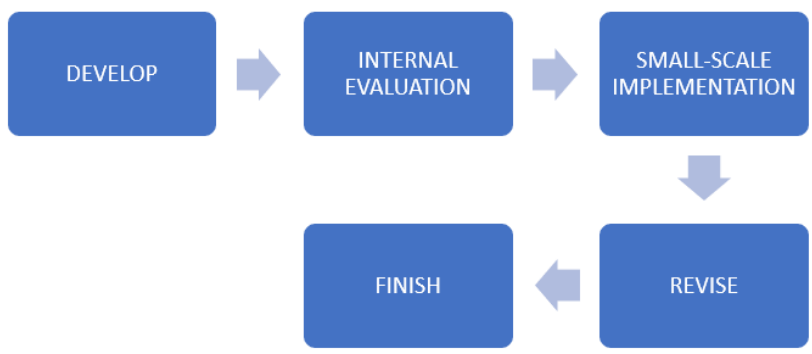

Figure 1. Development Process

From the picture above, the process of the development phase started with developing the product by using the software. After developing the multimedia, the researcher observed whether the multimedia fulfilled the criteria or not. If the criteria have been met, then the researcher implemented the multimedia with a small group of participants. The participants were 10 8th semester students of English Education Study Programme. The participants gave some comments regarding to the multimedia. The comments from the participants are mostly about the audio was too low. The other aspects like visuals and difficulty of exercise are not a problem. After receiving the comments from the participants, the researcher revised the multimedia based on those comments.

In developing phase, the researcher starts to make the layout for the multimedia. Layout is an essential part that supports the whole information being displayed in the electronic presentation. Power point provided many layout styles for the layout to choose for the presentation. The researcher believed that the chosen layout would attract the students to read and follow the information being displayed in the interactive multimedia. The researcher tried to design an original layout in order to make it more eye-catching and pleasing to see. 


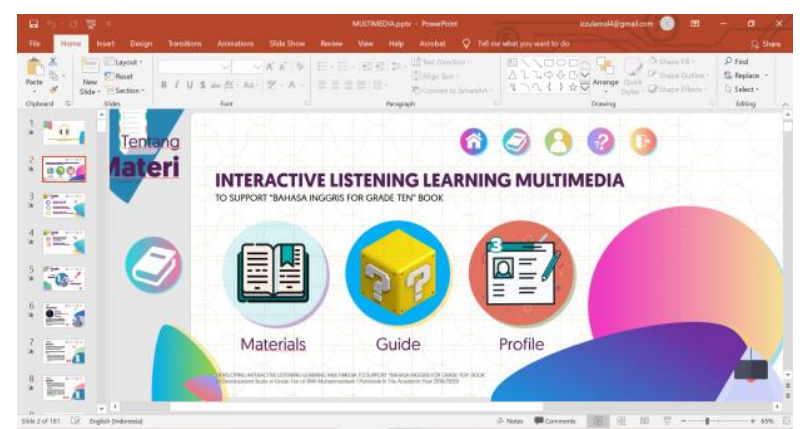

Figure 2. Making the layout

After finishing with the layout, the researcher considered that the dialogues and texts would be more appealing if there was the voice-over added. This voice over in this study belongs to the voice of the previously chosen characters as the voice-over in the dialogues and texts. To create the voice over, the researcher used "Animaker" by inserting the text in the provided clipboard and editing it before converting the text into speech as a file. Next, the researcher provided the following picture to show this process.

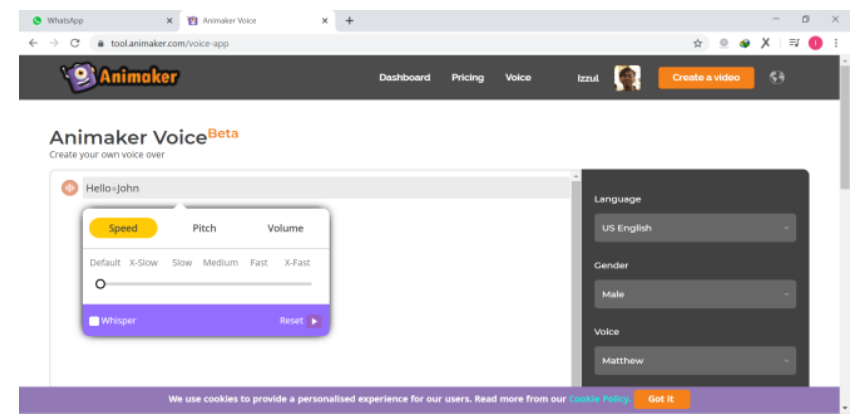

Figure 3. Adjusting the voice over

In this process, the researcher altered the voice by adjusting the rate, pitch, length pauses between the text, spelling, pronunciation, volume, and also the voice's gender.

After finished developing the multimedia, the researcher measured usability of the multimedia by using an internal evaluation. The researcher decided to use Internal evaluation because of the time limitation. The criteria that has been made in designing phase was used to make sure the multimedia is usable. Based on the first internal evaluation result, the researcher found that the audio level is too low. Some buttons are not working. There was also grammatical error in the text. It means that the interactive listening learning multimedia was not usable to support "Bahasa Inggris for Grade Ten" Book. The researcher should do a revision to fulfil all of the aspects in the criteria.

In the revision phase, the researcher increased the level of the audio to make it more audible. The researcher also fixed some buttons that were not working before. The grammatical errors in the text have been fixed in the revision phase. After the revision, the researcher can conclude that each aspect of the criteria has been fulfilled. It means that the interactive listening learning multimedia is 
usable to support "Bahasa Inggris for Grade Ten" Book. Moreover, because the quality of multimedia met all of the criteria, conducting a revision of the multimedia is unnecessary.

\section{Discussion}

The results of this research reveal that most of the students' objective in studying English was to do a communication by using English in daily activities. The students aim to be familiar with English pronunciation. The limitation in practicing listening activity was that the dialogues in the listening audio were too fast so they did not understand the meaning or message. The teacher preferred to use listening audio from the multimedia. The teacher also preferred that the materials for the multimedia were based on the latest curriculum. The teacher said the materials should be presented in correct spelling, structure, and grammar. The students preferred the listening audio that will be used in listening activity was in form of dialogue with pictures. The students also preferred daily life topic for the audio material. Regarding with the analyzing phase, Andersen and Brink (2013) claims that multimedia that contains sound, video, image, and animation to convey the materials are more interesting to the students. This will trigger the students to learn reading, by listening and by watching.

The researcher intended to develop a learning multimedia that contains listening audio in order to improve the teaching and learning process. Therefore, software for developing the multimedia has been chosen by considering to the features of the software itself. Microsoft PowerPoint 2019 was the first software. It can produce a presentation that contains different kind of graphic that can be useful to present the materials. The second software is a website named "Animaker". This website contains Text-To-Speech (TTS) feature that can produce voices from texts that has been inputted. Therefore, this website is called a dictation website that produce voices. The researcher used the internal evaluation in this research. The internal evaluation used to identify product usability of this electronic presentation.

The strength of this multimedia is the animated visual that makes the students interested with the materials. Animation can stimulate students' attention better than just a text. Students also will get clear interpretation. There are no static objects in each slides of the multimedia. The movement of every object in the multimedia will create the learning activity with the multimedia more engaging. The visual of the multimedia is contrast and visible. There are no texts that smaller than 12 points in order to make the students easier to see every content in the multimedia.

The weakness of the multimedia is the media only consists of three units only. The other units in the book were not included in the multimedia. Every units in the book are important to be taught in form of listening activity. The textbook does not contain listening audio for the students. The textbook only shows the materials in form of text and pictures. Therefore, the spoken language is will be produced by the teacher. The students were less interested to the audio because 
the chance of listening the audio is only once. The students would rather have a multimedia that provides audio materials. Therefore, a listening multimedia that covers all of the units from the book is needed.

\section{CONCLUSION AND SUGGESTION Conclusion}

Based on the research findings, the researcher sums the conclusion of the research. The conclusions are: (1) The interactive learning multimedia resulted for this research is created to support "Bahasa Inggris for Grade Ten" book with listening activities and exercises as the alternative supplementary materials based on the latest curriculum. (2) Interactive learning multimedia is usable to support "Bahasa Inggris for Grade Ten" Book.

\section{Suggestion}

Based on the conclusions, the researcher addressed some suggestions that can be taken into further consideration. The following suggestions are: (1) Developing teaching and learning activities by using multimedia were suggested to the English teacher. (2) The students should understand on how to operate this multimedia. Accessing all of the materials in this multimedia are allowed. (3) The natural speech from the "Animaker" website is suggested in order to make the user easier to comprehend the audio.

\section{REFERENCES}

Andersen, B. B., \& Brink, K. (2013). Multimedia in education curriculum. https:// doi.org/10.1007/978-0-387-78414-4_140

Branch, R. (2009). Instructional Design: The ADDIE Approach. In Springer. https:// doi.org/10.1017/CBO9781107415324.004

Cohen, L., Manion, L., \& Morisson, K. (2007). Research methods in education (6nd ed.).

Fisher, D. L. (2003). Using PowerPoint for ESL Teaching.

Harvey, L. (2004). Analytic Quality Glossary, Quality Research International,. http://www.qualityresearchinternational.com/glossary/

Ikhsanudin, I., Sudarsono, S. \& Salam, U. (2019). Using magic trick problem-based activities to improve engagement in a listening class. Journal of English Language Teaching Innovations and Materials, 1(1). http:/ / dx.doi.org/10.26418/jeltim.v1i1.31620

Mishra, S., \& Sharma, R. (2005). Interactive Multimedia in Education and Training. 13. https://doi.org/10.1017/CBO9781107415324.004

Nation, P., \& Newton, J. (2009). Teaching ESL/EFL Listening and Speaking. In Teaching ESL/EFL Listening and Speaking. https://doi.org/10.4324/9780203891704

Oxford English Dictionary. (n.d.). Oxford English Dictionary.

Purwanto, D., Ikhsanudin, I., \& Susilawati, E. (2017). Designing a Listening Workbook Using TBLT Approach for Marketing Students of SMK. Jurnal Pendidikan dan Pembelajaran Khatulistiwa, 6(6).

https://jurnal.untan.ac.id/index.php/jpdpb/article/view/20542 